\title{
Pengaruh Perkembangan Kegiatan Perdagangan dan Jasa terhadap Perubahan Penggunaan lahan di KaWasan Solo Baru
}

\author{
Dina Arifia, Soedwiwahjono, Rizon Pamardhi Utomo \\ Program Studi Perencanaan Wilayah dan Kota \\ Fakultas Teknik \\ Universitas Sebelas Maret, Surakarta \\ Email: arifiadina@gmail.com
}

\begin{abstract}
Solo Baru region has a very strategic location and were originally intended for residential areas, but then experienced a rapid development of economic activities. The development of economic activity is the most visible trade activities and services that continue to increase precisely since 2002. The development of trade and services activities is of course have an influence on land use changes that occur rapidly in Solo Baru region. Based on these issues, the formulation of the problem in this research is how the influence brought about by the development of the activity of trade in services to changes in land use. In line with these problems, this study aims to determine the effect of the development of trading activities and services to changes in land use Solo Baru Region. The method used is quantitative descriptive to determine the level of development to later described spatially. These results indicate that the development of trade and services activities has encouraged the development of other activities either similar activities (commercial) as well as supporting activities (housing, public services, and industry) so the impact on the provision of land. The need for this land that drives the changes in land use, both in terms of area, intensity, and land use patterns are formed. Developments are vertically making it more influential in the development of land compared to the intensity of the land area. Besides land development patterns that are formed are random pattern of development as the region woke formed does not have a specific shape (sporadic) and develop segmental.
\end{abstract}

Keywords: Activities Development, Trade and Services Activity, Land Use Change

\section{PENDAhuluaN}

Perkembangan kota yang paling dapat dilihat secara kasat mata adalah perkembangan sarana prasarana pendukung kegiatan masyarakat yang semakin beranekaragam. Secara fisik, perkembangan suatu kota dapat dicirikan dari penduduknya yang semakin bertambah dan semakin padat, bangunan-bangunannya yang semakin rapat dan wilayah terbangun yang cenderung semakin luas, serta semakin lengkapnya fasilitas kota yang mendukung kegiatan sosial dan ekonomi kota (Branch, 1995).

Perkembangan jumlah penduduk dan sarana pendukungnya tentu saja memiliki dampak dalam peningkatan perekonomian masyarakat kota tersebut. Perkembangan perekonomian suatu kota akan menjadi sebuah magnet tersendiri dalam peningkatan angka urbanisasi masuk sehingga kembali menambah jumlah penduduk dalam kota tersebut. Hal ini menjadi sebuah mata rantai yang terus berputar dan tiada putusnya, sehingga memiliki dampak yang besar bagi tuntutan penyediaan lahan dalam kota.

Tidak terkecuali pada Kawasan Solo Baru yang pada awalnya ditujukan untuk membentuk kawasan perumahan dengan sistem hunian berimbang, guna menampung luapan penduduk dari Kota Surakarta. Namun seiring dengan perkembangan waktu, Kawasan Solo Baru tidak lagi hanya memiliki fungsi sebagai daerah perumahan namun muncul pula fungsi-fungsi lain yang lebih kompleks, sehingga menyebabkan perubahan yang signifikan pada penggunaan lahan pada kawasan.

Perubahan penggunaan lahan pada Kawasan Solo Baru ini terlihat mulai pada tahun 2002 setelah kepulihan kondisi perekonomian pasca krisis moneter pada masa reformasi, ditandai dengan adanya penambahan jumlah fasilitas umum secara signifikan baik untuk fungsi perdagangan, 
jasa, industri, maupun hunian dengan mengkonversi lahan pertanian. (RUTR Kecamatan Grogol 2004-2013).

Sebelas sektor yang terbentuk pada Kawasan Solo Baru juga telah mengalami pergeseran dengan adanya penambahan fungsi perdagangan jasa dan industri (Kartiko, 1998). Dari sebelas sektor perumahan, terdapat tiga sektor yang ditambahkan fungsinya sebagai kawasan perdagangan dan jasa yang terletak pada posisi center di Solo Baru dan selanjutnya disebut sebagai pusat Kawasan Solo Baru, serta terdapat 4 sektor yang ditambahkan fungsinya sebagai kawasan industri dan terletak pada pinggiran kawasan.

Berdasar hal tersebut dapat dilihat bahwa keberadaan kegiatan perdagangan dan jasa yang berkembang pesat pada Kawasan Solo Baru telah berdampak pada perubahan penggunaan lahan. Perkembangan kegiatan perdagangan dan jasa ini memicu pertumbuhan kegiatan-kegiatan lain baik kegiatan sejenis maupun kegiatan pendukungnya. Perkembangan kegiatan secara terus menerus inilah yang mendorong adanya perubahan pada penggunaan lahan suatu kawasan (Jayadinata, 1999).

Berdasarkan uraian tersebut, penelitian ini bertujuan untuk mengetahui pengaruh dari perkembangan kegiatan perdagangan dan jasa terhadap perubahan penggunaan lahan Kawasan Solo Baru. Perubahan penggunaan lahan yang dilihat merupakan perubahan pada luas lahan, intensitas lahan, serta pola penggunaan lahan yang terbentuk.

\section{TINJAUAN TEORI}

\subsection{Kegiatan Perdagangan dan Jasa}

\subsubsection{Pengertian Kegiatan Perdagangan dan Jasa}

Perdagangan dan jasa berdasar UU No. 7 Tahun 2014 tentang Perdagangan diartikan sebagai tatanan kegiatan yang terkait dengan transaksi barang dan/ atau jasa di dalam negeri dan melampaui batas wilayah negara dengan tujuan pengalihan hak atas barang dan/atau jasa untuk memperoleh imbalan atau kompensasi.

\subsubsection{Jenis Kegiatan Perdagangan dan Jasa}

Chapin (1997) menyebutkan jenis kegiatan perdagangan antara lain adalah pertokoan dan dealer, sedangkan kegiatan jasa antara lain adalah perkantoran, keuangan, asuransi, hotel, restoran, dan rekreasi. Sedangkan Kyle (2000) menyebutkan bahwa kegiatan perdagangan dan jasa ini secara umum dapat digolongkan ke dalam commercial real estate yaitu pada jenis office building (penyedia jasa) dan retail property (area komersil/ perdagangan produk).

\subsubsection{Perkembangan Kegiatan Perdagangan dan Jasa}

Kegiatan perdagangan dan jasa memiliki kaitan yang sangat erat dengan perkembangan suatu kota. Hal ini sesuai dengan pendapat Adisasmita (2005) yang menyatakan bahwa perkembangan kota dapat mencakup kegiatan pelayanan ekonomi bagi kawasan di sekitarnya sehingga pertumbuhan kota sangat dikaitkan dengan kepentingan penduduknya terutama terkait kegiatan ekonominya.

Selanjutnya dalam menentukan perkembangan kegiatan perdagangan dan jasa pada suatu kawasan, dapat digunakan beberapa variabel. Jayadinata (1999) mengemukakan bahwa dalam perkembangan kegiatan suatu kawasan dapat dilihat dari peningkatan sarana prasarana yang menandakan perkembangan jumlah kegiatan serta perluasan skala pelayanan yang ditunjukkan dengan jangkauan kegiatan yang semakin luas dilihat dari asal barang dan target pemasaran (konsumen).

Sedangkan Zahnd (1999) bahwa perkembangan kegiatan pada perkotaan tidak hanya terjadi secara horizontal melainkan juga secara vertikal. Hal ini dapat dikaitkan dengan luas lantai kegiatan tersebut yang tidak hanya dihitung berdasarkan luas satu lantai melainkan juga dengan luas lantai di 
atasnya apabila kegiatan tersebut menempati bangunan bertingkat.

\subsection{Penggunaan Lahan}

\subsubsection{Pengertian Penggunaan Lahan}

Lahan adalah seluruh kemampuan muka daratan beserta gejala di bawah permukaannya yang bersangkut paut dengan pemanfaatannya bagi manusia (Cooke, 1983). Berdasar hal tersebut dapat disimpulkan bahwa lahan merupakan seluruh daerah pada permukaan bumi yang menjadi tempat bagi makhluk hidup dalam menjalankan kegiatannya sekaligus menjadi salah satu sumber daya bagi makhluk hidup dalam melakukan kehidupannya tersebut.

\subsubsection{Jenis Penggunaan Lahan}

Yeates dalam Marangkup (2006) menyebutkan bahwa penggunaan lahan dalam suatu wilayah dapat terdiri dari permukiman, industri, komersil, jalan, tanah publik, serta tanah kosong. Berbeda dengan Anderson dalam Utomowati (2012) mengklasifikasikan penggunaan lahan perkotaan menjadi guna lahan hunian, penggunaan umum, kompleks industri dan komersil, serta lahan sedang dibangun. Terakhir dalam Malingreau (1978) klasifikasi guna lahan di Indonesia berdasarkan pada data penginderaan jauh dapat dibedakan menjadi permukiman perkotaan, perdagangan jasa dan industri, kelembagaan, transportasi komunikasi, lahan terbangun lainnya, serta bukan lahan terbangun.

Berdasar teori-teori tersebut dapat disimpulkan bahwa jenis penggunaan lahan yang digunakan dalam penelitian ini adalah perumahan, perdagangan jasa, fasilitas pelayanan, industri, persawahan, dan ruang terbuka.

\subsubsection{Perubahan Penggunaan Lahan}

Perubahan penggunaan lahan dapat didefinisikan dengan bertambahnya suatu penggunaan lahan dari satu tipe penggunaan ke penggunaan lain yang diikuti dengan berkurangnya tipe penggunaan lahan yang lainnya dalam kurun masa tertentu (Wahyunto, 2001). Perubahan penggunaan lahan juga dapat dikaitkan dengan luas lantai bangunan yang ada (Zahnd, 1999) sehingga berpengaruh pada intensitas lahan yang dijabarkan dalam nilai KDB dan KLB.

\subsubsection{Pola Penggunaan Lahan}

Bintarto (1977) menyebutkan bahwa perubahan penggunaan lahan akan dapat menyebabkan terjadinya perubahan pola penggunaan lahan pula. Menurut Aziz (2014), pola penggunaan lahan pada suatu kawasan dapat digambarkan menjadi tiga pola perkembangan secara umum yaitu:

1. Pola acak (Leap-frog Development) merupakan pola perkembangan dengan arah yang melompat, berbentuk sporadis, berkembang secara segmental dan memiliki dampak yang tidak efisien.

2. Pola Memanjang (Linear Development) merupakan pola perkembangan dengan arah mengikuti jaringan transportasi utama, berbentuk memanjang/ menjari, berkembang secara segmental dan memiliki dampak yang cukup efisien.

3. Pola Konsentris (Concentric Development) merupakan pola perkembangan yang melapisi batas terluar kota, berbentuk melingkar kompak, berkembang secara komprehensif dan memiliki dampak yang sangat efisien.

\subsection{Pengaruh Perkembangan}

Kegiatan Perdagangan dan Jasa terhadap Perubahan Penggunaan Lahan

Berdasar pendapat Sujarto yang dijabarkan oleh Adisasmita (2005), faktorfaktor perkembangan dan pertumbuhan yang bekerja pada suatu kota dapat menumbuhkan dan mengembangkan kota pada suatu arah tertentu yang dipengaruhi oleh tiga faktor 
utama yaitu faktor manusia, faktor kegiatan, dan faktor pergerakan. Ketiga faktor ini akan tergabung secara fisik membentuk tuntutan kebutuhan akan ruang sehingga berimplikasi pada perubahan pola penggunaan lahan suatu kawasan.

Berdasar hal tersebut dapat dilihat bahwa salah satu faktor yang menyebabkan terjadinya perubahan penggunaan lahan adalah faktor kegiatan. Perkembangan kegiatan perdagangan dan jasa dapat memicu perubahan penggunaan lahan di sekitarnya. Perubahan penggunaan lahan tersebut dapat berupa perubahan dalam luasannya, intensitasnya maupun perubahan pada polanya.

\section{METODE PENELITIAN}

\subsection{Ruang Lingkup Penelitian}

Penelitian dilakukan pada Kawasan Solo Baru yang dibatasi secara fungsional yaitu pada kawasan dengan dominasi kegiatan perdagangan jasa sesuai dengan arahan dari masterplan pengembangan Kawasan Solo Baru, dokumen tata ruang, serta fenomena pada lapangan. Waktu penelitian yang digunakan adalah dengan melihat perkembangan baik kegiatan perdagangan jasa maupun perubahan penggunaan lahan dari tahun 2002 hingga 2016.

\subsection{Metode Analisis Data}

Secara keseluruhan metode analisis yang digunakan adalah teknik analisis eksplanasi kualitatif dan deskriptif spasial dengan penjelasan sebagai berikut:

\subsubsection{Analisis Kuantitatif}

Analisis kuantitatif digunakan untuk mengetahui perkembangan jumlah sarana, jangkauan pelayangan, jumlah pelaku, dan luas lantai kegiatan perdagangan dan jasa serta perkembangan luas dan intensitas lahan dari tahun 2002-2016. Perubahan pola penggunaan lahan tidak dianalisis dengan kuantitatif karena pola guna lahan tidak dapat diberi nilai atau diberi peringkat tertentu.

Nilai perkembangan dari masingmasing sub variabel dihitung dengan rumus perkembangan sebagai berikut:

$$
\begin{aligned}
& \mathrm{p}=\frac{\mathrm{y}-\mathrm{x}}{\mathrm{x}} \cdot 100 \% \\
& \mathrm{p}: \text { persentase peningkatan } \\
& \mathrm{y}: \text { nilai pada tahun } 2016 \\
& \mathrm{x}: \text { nilai pada tahun } 2002
\end{aligned}
$$

Hasil kuantitatif diberi skala rendah, sedang, dan tinggi dengan besaran persentase klasifikasi dihitung dengan nilai interval nilai perkembangan pada masing-masing sub variabel.

\subsubsection{Analisis Deskriptif Spasial}

Analisis deskriptif spasial digunakan untuk menjelaskan pengaruh yang terbentuk secara lebih spasial (keruangan). Analisis deskriptif spasial ini digunakan untuk menjelaskan pengaruh yang terbentuk antara perkembangan kegiatan perdagangan jasa dengan perubahan luas, intensitas, dan pola penggunaan lahan. Analisis ini dilakukan dengan menjelaskan secara deskriptif eksplanatif dengan interpretasi peta.

\section{HASIL PENELITIAN}

\subsection{Perkembangan Perdagangan dan Jasa}

Kegiatan

Analisis perkembangan kegiatan perdagangan dan jasa dilakukan dengan metode kuantitatif. Analisis ini dihitung dengan menghitung besar perkembangan masing-masing variabel dengan rumus yang telah disebutkan pada bagian metode penelitian. Hasil perhitungan tersebut dapat dilihat dalam Tabel 1.

Tabel 1. Hasil Perkembangan Kegiatan Perdagangan dan Jasa

\begin{tabular}{|c|c|c|}
\hline Variabel & $\begin{array}{c}\text { Besar } \\
\text { Perkemban } \\
\text { gan }\end{array}$ & $\begin{array}{c}\text { Klasifikasi } \\
\text { Perkemban } \\
\text { gan }\end{array}$ \\
\hline $\begin{array}{l}\text { Jumlah } \\
\text { Sarana }\end{array}$ & $90,52 \%$ & Rendah \\
\hline
\end{tabular}




\begin{tabular}{|l|c|c|}
\hline $\begin{array}{l}\text { Jangkauan } \\
\text { Pelayanan }\end{array}$ & $78,29 \%$ & Sedang \\
\hline $\begin{array}{l}\text { Jumlah } \\
\text { Pelaku }\end{array}$ & $103,07 \%$ & Sedang \\
\hline Luas Lantai & $464,31 \%$ & Tinggi \\
\hline
\end{tabular}

\subsection{Perubahan Penggunaan Lahan}

Analisis perubahan penggunaan lahan dibagi menjadi 2 analisis yaitu analisis kuantitatif dan analisis deskriptif spasial. Analisis kuantitatif digunakan untuk mengetahui perubahan luas lahan dan intensitas lahan pada Kawasan Solo Baru. Sedangkan analisis deskriptif spasial digunakan untuk mengetahui perubahan pola penggunaan lahan pada kawasan. Seperti halnya dengan analisis kuantitatif pada perkembangan kegiatan perdagangan dan jasa, analisis kuantitatif pada perubahan penggunaan lahan juga menggunakan rumus yang sama. Berdasarkan hasil perhitungan tersebut, diperoleh hasil yang dapat dilihat pada Tabel 2.

Tabel 2. Hasil Perubahan Luas dan Intensitas Lahan

\begin{tabular}{|l|c|c|}
\hline Variabel & $\begin{array}{c}\text { Besar } \\
\text { Perkemba } \\
\text { ngan }\end{array}$ & $\begin{array}{c}\text { Klasifikasi } \\
\text { Perkemban } \\
\text { gan }\end{array}$ \\
\hline $\begin{array}{l}\text { Luas } \\
\text { Lahan }\end{array}$ & $25,20 \%$ & Rendah \\
\hline $\begin{array}{l}\text { Intensitas } \\
\text { Lahan }\end{array}$ & $21,28 \%$ & Sedang \\
\hline
\end{tabular}

Sesuai dengan hasil perhitungan pada perkembangan luas lahan yang menunjukkan perkembangan kawasan tidak terbangun menjadi kawasan terbangun, maka perkembangan pola penggunaan lahan yang akan dilihat adalah perkembangan pola yang dibentuk oleh kawasan terbangun dan tidak terbangun yang ada pada Kawasan Solo Baru.

Kawasan Solo Baru pada tahun 2002 dan 2016, secara keseluruhan dapat dilihat telah menunjukkan adanya kecenderungan perkembangan pola penggunaan lahan secara acak. Perkembangan kawasan terbangun yang terbentuk memiliki arah yang acak atau tidak terpola, sehingga memberikan bentuk sporadis. Hal ini dikarenakan pada Kawasan Solo Baru sejak tahun 2002 masih banyak terdapat ruang terbuka baik area persawahan maupun lahan kosong yang tersebar secara merata pada seluruh kawasan, baik di pusat maupun pinggiran kawasan.

Hal inilah yang memicu pembentukan pola perkembangan secara acak karena pihak pembangun memilih tanah-tanah kosong tersebut pada lokasi yang dinilai menguntungkan bagi mereka, baik dari segi letak hingga dari segi harga lahan. Pada peta perkembangan Kawasan Solo Baru juga dapat dilihat bahwa perkembangan yang terjadi bersifat segmental, yaitu hanya terbangun pada beberapa bagian wilayah saja.

\subsection{Pengaruh Perkembangan Kegiatan Perdagangan Jasa terhadap Perubahan Penggunaan Lahan}

\subsubsection{Pengaruh terhadap Luas Lahan}

Secara spasial, terdapat temuan bahwa perkembangan kegiatan perdagangan dan jasa pada Kawasan Solo Baru telah memberikan pengaruh yaitu adanya penambahan luas untuk kawasan terbangun akibat kegiatan yang sejenis maupun kegiatan pendukung yang muncul. Perluasan kawasan terbangun seperti guna lahan komersil, perdagangan jasa, dan fasilitas umum ini terjadi dengan menempati kawasan tidak terbangun sehingga telah mengurangi luasan lahan kosong tersebut (Lihat Lampiran 1).

Hal ini sesuai dengan teori bahwa semua kegiatan yang berkembang akan memerlukan lahan sebagai wadahnya (Jayadinata, 1999). Meski demikian penambahan luas kawasan terbangun yang terjadi pada Kawasan Solo Baru masih tergolong rendah atau hanya ada sedikit kawasan yang terdampak oleh perkembangan kegiatan perdagangan dan jasa ini. 


\subsubsection{Pengaruh terhadap Intensitas Lahan}

Secara spasial, terdapat temuan bahwa perkembangan kegiatan perdagangan jasa pada Kawasan Solo Baru telah mendorong dan berdampak pada perkembangan intensitas lahan yang ditilik dari nilai KDB dan KLB (Lihat Lampiran 3).

Hal ini dikarenakan perkembangan kegiatan perdagangan jasa yang berdampak pada kegiatan itu sendiri maupun pada kemunculan kegiatan pendukungnya. Perkembangan jumlah dan jenis kegiatan inilah yang kemudian menyebabkan adanya pembangunan gedung sebagai sarana kegiatan yang akan mendorong perkembangan intensitas lahan di Kawasan Solo Baru.

\subsubsection{Pengaruh terhadap Pola Guna Lahan}

Perkembangan pola yang terlihat tidak bersifat menyeluruh atau hanya pada sebagian-sebagian kawasan (segmented). Perkembangan segmented ini juga tidak memanjang mengikuti jalan melainkan tersebar acak dan tidak memiliki bentuk yang jelas. Berdasarkan fenomena yang terdapat pada lapangan, pola penggunaan lahan yang berkembang lebih bersifat acak, bukan konsentris maupun linear (Lihat Lampiran 2).

Hal ini juga dipicu dari kondisi awal (tahun 2002) bahwa pola penggunaan lahan Kawasan Solo Baru adalah terpola secara acak. Pada tahun 2002 persebaran kawasan berpola sporadic karena tidak mengikuti jaringan jalan (bukan linear) dan belum memiliki pusat atau inti kota (bukan konsentris). Kawasan terbangun dan kawasan tidak terbangun pada tahun 2002 tersebar secara merata mulai dari pusat hingga pinggiran kawasan. Hal inilah yang berdampak pada pembentukan pola penggunaan lahan pada tahun 2016 di mana kawasan terbangun yang terbentuk menempati kawasan-kawasan tidak terbangun yang ada.

Berdasarkan pembahasan itulah diperoleh temuan bahwa dalam perkembangan selama 15 tahun yaitu dari tahun 2002 hingga tahun 2016, pola penggunaan lahan pada Kawasan Solo Baru masih tetap yaitu pola penggunaan lahan secara acak. Meskipun demikian perbedaan yang muncul adalah kemunculan kawasan terbangun pada Jalan Ir. Soekarno di Desa Madegondo yang cukup dominan yaitu pada kompleks The Park Mall. Keberadaan kawasan inilah yang ke depannya memiliki potensi untuk memicu perubahan pola penggunaan lahan menjadi linear bahkan konsentris karena berdasarkan struktur ruangnya, kawasan ini telah menjadi pusat Kawasan Solo Baru pada tahun 2016.

\section{KESIMPULAN}

Kegiatan perdagangan dan jasa pada Kawasan Solo Baru yang perkembangannya dilihat dari jumlah sarana, jangkauan kegiatan, jumlah pelaku, serta luas lantai kegiatan kesemuanya menunjukkan peningkatan perkembangan. Begitu halnya dengan guna lahan yang ada menunjukkan adanya perubahan luas yaitu penambahan luas kawasan terbangun dan peningkatan intensitas lahan yang dilihat dari nilai KDB dan KLB.

Kegiatan perdagangan dan jasa yang ada telah mendorong adanya perkembangan kegiatan lain, baik kegiatan sejenis (komersil) maupun kegiatan pendukung (perumahan, pelayanan umum, dan industri). Perkembangan kegiatan ini tentunya memerlukan lahan sebagai wadahnya sehingga telah berdampak pada perubahan guna lahan di Kawasan Solo Baru.

Berdasar hasil analisis diketahui bahwa pengaruh yang ditimbulkan pada perubahan luas lahan adalah rendah, perubahan intensitas lahan yang terjadi adalah sedang. Dengan demikian dapat dilihat bahwa perkembangan yang terjadi lebih bersifat vertikal, sehingga perubahan 
intensitas yang terjadi lebih tinggi dibanding perubahan luas lahan. Sedangkan pola guna lahan yang terbentuk adalah pola acak (leapfrog development), karena perkembangan terjadi secara segmented pada beberapa bagian kawasan tanpa adanya bentuk tertentu.

\section{REFERENSI}

Adisasmita, Raharjo H. 2005. Dasar-dasar Ekonomi Wilayah. Jogjakarta: Graha Ilmu.

Aziz, Rudi dan Asrul. 2014. Pengantar Sistem dan Perencanaan Transportasi. Jogjakarta: Deepublish.

Bintarto, R. 1977. Pengantar Geografi Kota. Yogyakarta: U.P. Spring.

Branch, M.C. 1995. Perencanaan Kota Komprehensif, Pengantar dan Penjelasan. Yogyakarta: Gadjahmada University Press.

Chapin, F. Stuart Jr. 1997. Urban Land Use Planning, Third Edition. Chicago: University of Illinois Press.

Cooke, P. 1983. Theory of Planning and Spatial Development. London: Hutchinson and Co Publiser LTD.

Jayadinata, T. Johara. 1999. Tata Guna Tanah dalam Perencanaan Pedesaan Perkotaan dan Wilayah. Bandung: ITB.

Kartiko dkk. 1998. Sekilas Sejarah Perjuangan Solo Baru Kota Mandiri. Sukoharjo: Cipta Sarana Megah.

Kyle, Robert C. 2000. Property Management (Sixth Edition). Chicago: Dearborn Real Estate Education.
Malingreau, 1978. Penggunaan Lahan Pedesaan Penafsiran Citra Untuk Inventarisasi dan Analisanya. Yogyakarta: Fakultas Geografi UGM Press.

Marangkup, Hubert dan Eka Ulin S. 2006. Identifikasi Pola Pengembangan Daerah Pinggiran dan Pola Jaringan Jalan Kota Semarang. [Tesis]. Semarang: Universitas Diponegoro.

Rencana Umum Tata Ruang (RUTR) Kecamatan Grogol Tahun 2004-2013. BAPPEDA Kabupaten Sukoharjo.

Undang-undang No. 7 Tahun 2014 tentang Perdagangan.

Utomowati, Rahning. 2012. Pemanfaatan Citra Landsat 7 Enhanced Thematik Mapper Untuk Penentuan Wilayah Prioritas Penanganan Banjir Berbasis Sistem Informasi Georafis [Prosiding Seminar Nasional Penginderaan Jauh dan Sistem Informasi Geografis 2012]. Surakarta: Muhammadiyah University Press.

Wahyunto, et.al.2001. Studi Perubahan Penggunaan Lahan Di Sub DAS Citarik, Jawa Barat Dan DAS Kaligarang, Jawa Tengah. [Prosiding Seminar Nasional Multifungsi Lahan Sawah]. Bogor: Departemen Pertanian, Badan Penelitian dan Pengembangan, Pertanian Pusat Penelitian dan Pengembangan Tanah dan Agroklimat.

Zahnd, Markus. 1999. Perancangan Kota Secara Terpadu. Yogyakarta: Kanisius. 
Lampiran 1

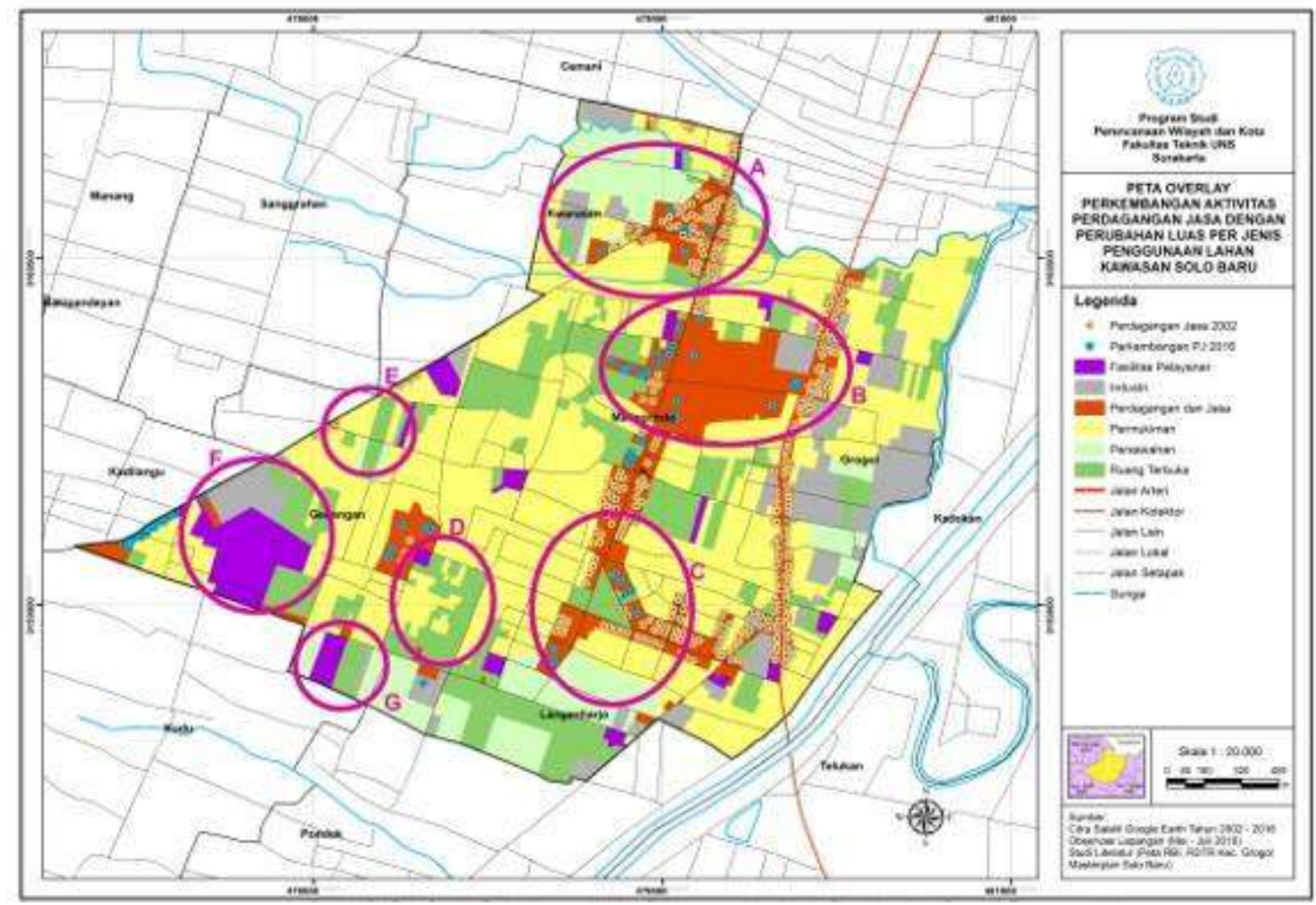

Gambar 1. Peta Pengaruh terhadap Perubahan Luas Per Jenis Guna Lahan (Citra Satelit Google Earth Tahun 2002-2016)

Lampiran 2

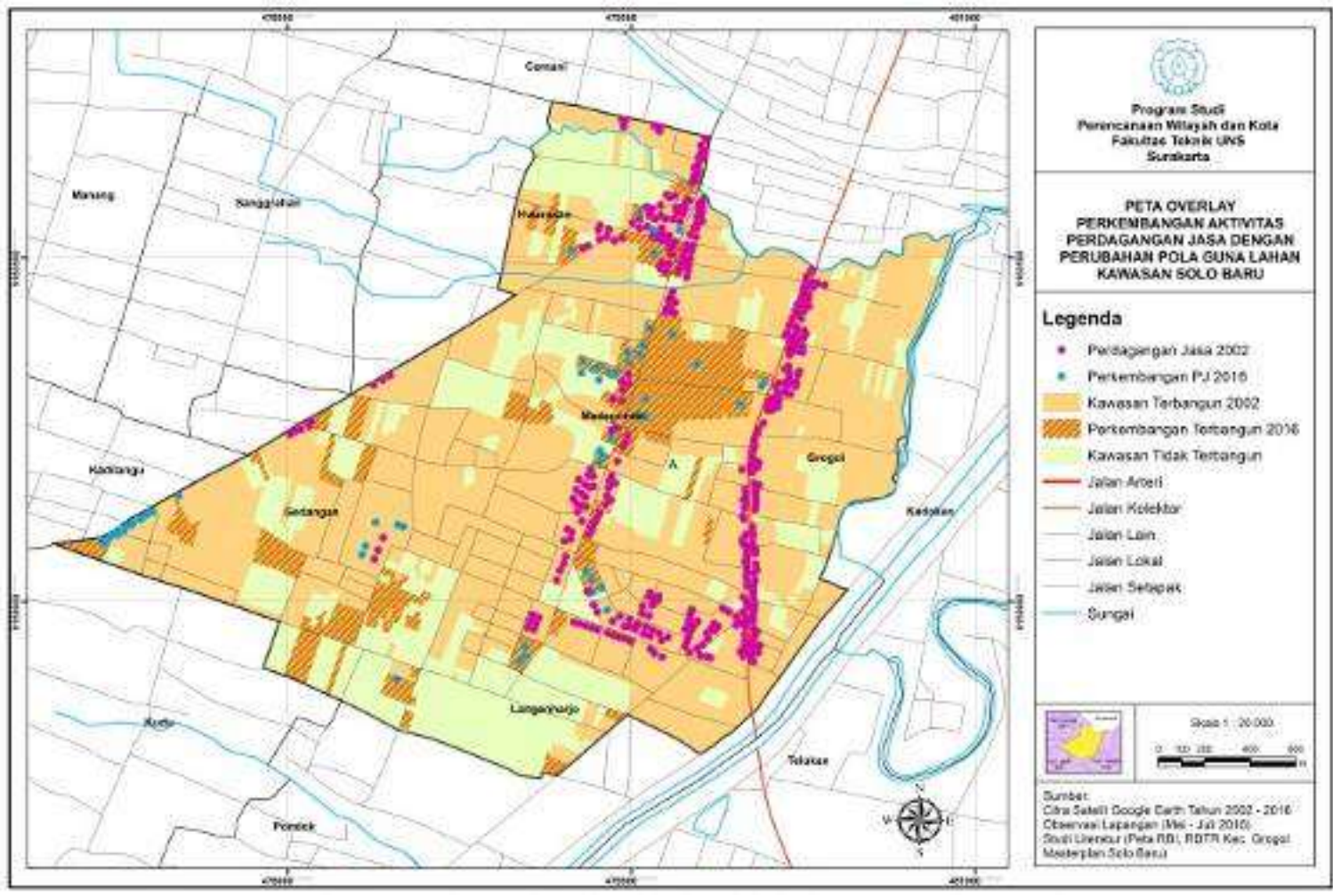

Gambar 2. Peta Pengaruh terhadap Pola Penggunaan Lahan (Citra Satelit Google Earth Tahun 2002-2016) 
Lampiran 3

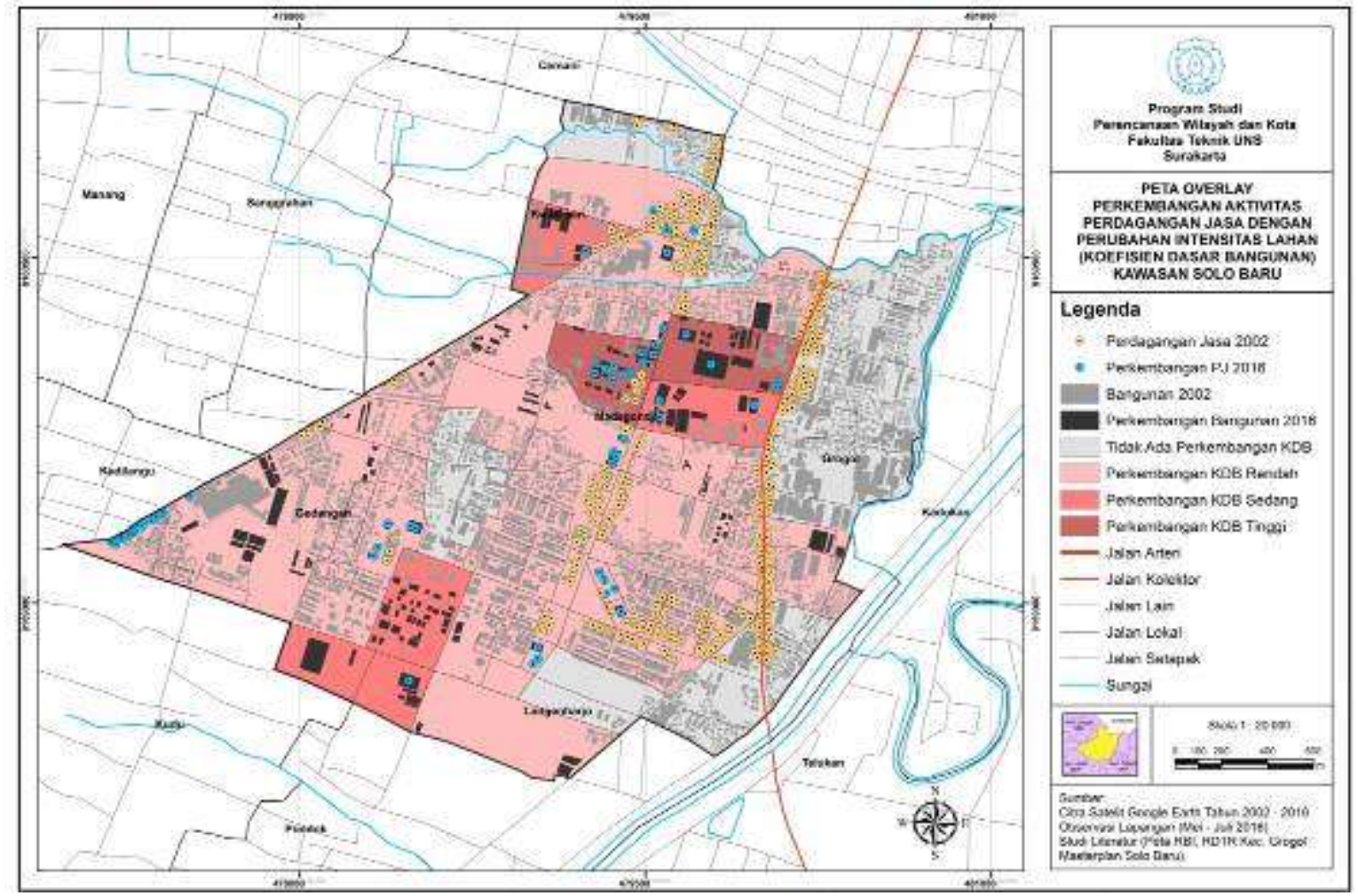

Gambar 3. Peta Pengaruh terhadap Perubahan Intensitas Lahan (KDB)

(Citra Satelit Google Earth Tahun 2002-2016)

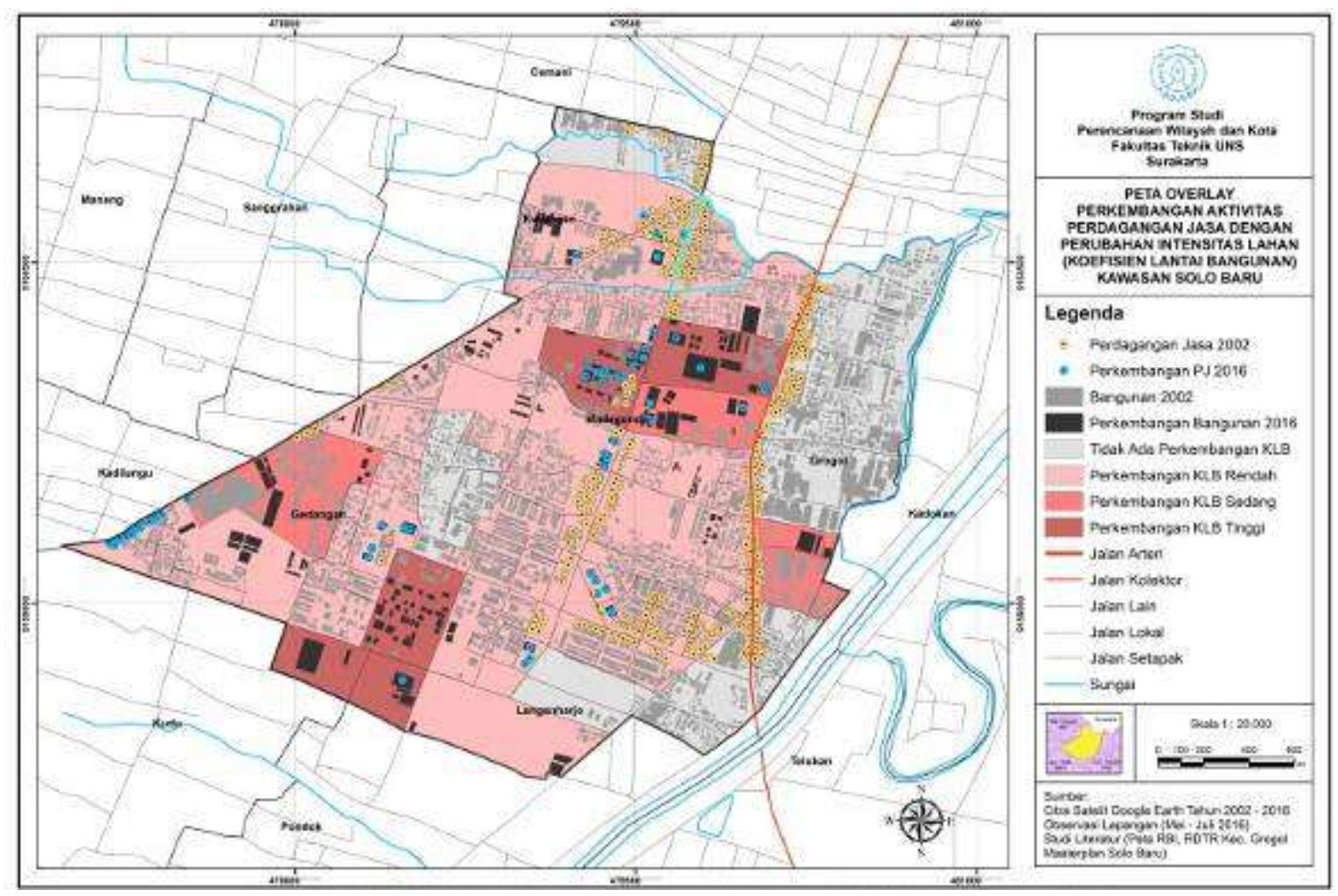

Gambar 4. Peta Pengaruh terhadap Perubahan Intensitas Lahan (KLB)

(Citra Satelit Google Earth Tahun 2002-2016) 